\title{
Genetic progress of grain quality of flooded-irrigated rice cultivars in the state of Rio Grande do Sul, Brazil
}

\author{
Eduardo Anibele Streck(1), Ariano Martins de Magalhães Júnior(2), Gabriel Almeida Aguiar(1), \\ Paulo Henrique Karling Facchinello(1), Lais Perin ${ }^{(1)}$, Paulo Ricardo Reis Fagundes ${ }^{(2)}$ \\ and Antônio Costa de Oliveira(1)
}

\begin{abstract}
(1)Universidade Federal de Pelotas, Avenida Eliseu Maciel, s/no, Caixa Postal 354, CEP 96010-610 Capão do Leão, RS, Brazil. E-mail: streck.eduardo@gmail.com,gabrielalmeidaaguiar@yahoo.com.br,phfacchinello@gmail.com, laisp.agro@gmail.com, acostol@cgfufpel.org (2)Embrapa Clima Temperado, Rodovia BR-392, Km 78, $9^{\circ}$ Distrito, Monte Bonito, Caixa Postal 321, CEP 96010-971 Pelotas, RS, Brazil. E-mail: ariano.martins@embrapa.br, paulo.fagundes@embrapa.br
\end{abstract}

Abstract - The objective of this work was to determine the genetic progress of grain quality attributes of flooded irrigated rice (Oryza sativa) cultivars in the state of Rio Grande do Sul, Brazil, between 1972 and 2016. The genetic estimates followed an approach based on the comparative analysis of 25 cultivars released by Embrapa's breeding program over this period. The experiment was implemented in four producing regions of the state of Rio Grande do Sul: Sul, Campanha, Planície Costeira Interna, and Planície Costeira Externa. The following significant genetic gains were observed: $0.20 \%$ per year, for percentage of whole grains after processing; $-1.38 \%$ per year, for percentage of chalky kernels and white-core grains; $-0.77 \%$ per year, for total chalky area; $-0.08 \%$ per year, for total whiteness; and $-0.82 \%$ per year, for non-vitreous grain whiteness. Most cultivars released have high amylose content and a low gelatinization temperature. Therefore, the breeding program presented significant annual genetic progresses between 1972 and 2016 for the main attributes of grain quality, and made cultivars available according to the national demand for grain quality in the several segments of the rice production industry.

Index terms: Oryza sativa, breeding, chalky area, chalky kernels, genetic gain, industrial yield.

\section{Progresso genético da qualidade dos grãos de cultivares de arroz irrigado por inundação no Rio Grande do Sul}

Resumo - O objetivo deste trabalho foi determinar o progresso genético de atributos de qualidade de grãos de cultivares de arroz (Oryza sativa) irrigado por inundação no Rio Grande do Sul, entre 1972 e 2016. As estimativas genéticas seguiram a abordagem baseada na análise comparativa das 25 cultivares lançadas pelo programa de melhoramento genético da Embrapa ao longo desse período. O experimento foi implementado em quatro regiões produtoras do Estado do Rio Grande do Sul: Sul, Campanha, Planície Costeira Interna e Planície Costeira Externa. Observaram-se ganhos genéticos significativos de: 0,20\% ao ano, para percentual de grãos inteiros após o beneficiamento; $-1,38 \%$ ao ano, para percentual de grãos gessados e centro branco; $-0,77 \%$ ao ano, para área gessada total; $-0,08 \%$ ao ano, para brancura total; e $-0,82 \%$ ao ano, para brancura não vítrea dos grãos. A maioria das cultivares lançada apresenta alto teor de amilose e baixa temperatura de gelatinização. Portanto, o programa de melhoramento genético apresentou progressos genéticos anuais significativos entre 1972 e 2016 para os principais atributos de qualidade dos grãos, tendo disponibilizado cultivares de acordo com a demanda nacional quanto à qualidade dos grãos nos diversos segmentos da cadeia produtiva do arroz.

Termos para indexação: Oryza sativa, melhoramento genético, área gessada, grãos gessados, ganho genético, rendimento industrial.

\section{Introduction}

Rice (Oryza sativa L.) is the basis of the diet and the main energy source for more than half of the world's population (Lee et al., 2011). Therefore, high cereal yields are increasingly required to maintain global food security (Zeigler \& Barclay, 2008). In Brazil, this crop is of extreme social and economic importance, with an annual production of approximately 12 million tons in the 2016/2017 harvest, supplying the national consumption demand for this cereal. The state of Rio Grande do Sul, where the flooded-irrigated system is adopted for this crop, is responsible for more than 
$70 \%$ of the national production (Acompanhamento..., 2017).

The consumer in the domestic scenario is very demanding regarding grain quality. Consumers prefer polished white rice of the long and thin class (subspecies Indica), which presents soft grains that remain loose after cooking. This pattern of consumption is mainly attributed to the incidence of undesirable physical or biochemical defects in grains.

The physical attributes related to grains provide us with important parameters for the knowledge of the appearance of the cereal after cooking. Most components of polished rice comprise starch (up to $95 \%$ of dry weight), protein $(5.0-7.0 \%)$ and lipids $(0.5-1.0 \%)$. Therefore, the amount of these compounds affects the sensory properties of the cereal (Fitzgerald et al., 2008a).

The grain composition and its fractions are subject to genetic differences, environmental variations, handling, processing, and storage (Zhou et al., 2002), which may change the nutritional characteristics of the grain.

In the process of marketing rice, it is necessary to consider specific requirements of the various segments involved in the production and commercial processes of that cereal. It is possible to highlight the physical quality of the grain expressed by income in the processing, grain yield, size, and appearance (Mingotte et al., 2012). Another important physical property related to rice grain quality is translucency (Edwards et al., 2017). In many grains, translucency is interrupted by opaque areas in the endosperm called white centers, chalky kernel or chalky areas (Smiderle \& Dias, 2008). This opacity occurs in grains due to an arrangement between starch and protein granules arising from adverse climatic and crop conditions, as well as from genetic factors (Fitzgerald et al., 2008b). Such parameters are related to defects associated with rice grains in conjunction with their quality characteristics. This determines market value and plays a fundamental role in the adoption and, consequently, in the development of new cultivars.

The development of new cultivars with superior characteristics, providing maximum productivity and quality, is the greatest challenge for breeders seeking to overcome challenges in the development of technologies compatible with the reality of flooded-irrigated rice cultivation. At a productivity level, irrigated rice breeding programs are advanced, and there are several studies worldwide showing the contribution of breeding to this trait (Breseghello et al., 1999; Tabien et al., 2008; DoVale et al., 2012).

The intensification of the selection pressure for grain quality attributes is still very recent in breeding programs. Therefore, there are still no consolidated breeding techniques and studies on the genetic contribution related to this trait. In this sense, this study, which addresses the genetic progress of physical quality attributes of grains, is a great contribution to the scientific area and the productive chain of this cereal.

In order to improve this crop for the South region of Brazil, research projects have developed cultivars and technologies in line with the demand of the various segments of the cereal production chain, among which, grain quality after processing. The most recent cultivars released with these characteristics are BRS Pampa (Magalhães Júnior et al., 2012) and BRS Pampeira (Magalhães Júnior et al., 2017). The cultivar BR IRGA 409 is also worth mentioning because it is an old cultivar, released in 1979, still cultivated in Rio Grande do Sul due to its good grain quality.

The objective of this work was to determine the genetic progress of grain quality attributes of flooded-irrigated rice cultivars in the state of Rio Grande do Sul, Brazil, between 1972 and 2016.

\section{Materials and Methods}

The experiment was conducted in the 2015/2016 harvest in four locations in the state of Rio Grande do Sul: Estação Experimental Terras Baixas of Embrapa Clima Temperado in the municipality of Capão do Leão $\left(31^{\circ} 48^{\prime} 59^{\prime \prime} \mathrm{S}, \quad 52^{\circ} 27^{\prime} 48^{\prime \prime} \mathrm{W}\right)$, a rice-producing area of the south zone, characterized by a Planossolo Háplico Eutrófico solódico (Solodic Eutrophic Planosol); rural property in municipality of Nova Esperança do Sul $\left(29^{\circ} 27^{\prime} 16^{\prime \prime} \mathrm{S}, 5^{\circ} 46^{\prime} 27^{\prime \prime} \mathrm{W}\right)$, a riceproducing area of Campanha region, characterized by a Planossolo Háplico Eutrófico (Eutrophic Planosol); Estação Experimental do Arroz, of Associação dos Usuários do Perímetro de Irrigação do Arroio Duro, in municipality of Camaquã (30 $\left.51^{\prime} 58^{\prime \prime} \mathrm{S}, 51^{\circ} 47^{\prime} 48^{\prime \prime} \mathrm{W}\right)$, a rice-producing area of the inner coastal plain, characterized by a Planossolo Háplico Eutrófico solódico (Solodic Eutrophic Planosol); and rural property at the municipality of Mostardas $\left(31^{\circ} 03^{\prime} 08^{\prime \prime} \mathrm{S}\right.$, $\left.50^{\circ} 54^{\prime} 29^{\prime \prime} \mathrm{W}\right)$, a rice-producing area of the outer coastal 
plain, characterized by a Planossolo Háplico Eutrófico solódico (Solodic Eutrophic Planosol).

The design for all study environments was randomized complete blocks with three replicates. The experimental units consisted of plots composed of four 5-m-long lines at a spacing of $0.17 \mathrm{~m}$ between rows. The useful plot area consisted of the four central meters of two internal rows to exclude undesirable effects on borders. Irrigation was performed using a permanent flood system until the final maturation stage of the genotypes. Sowing was performed at a density of $100 \mathrm{~kg} \mathrm{ha}^{-1}$ of viable seeds, using a mechanical seed plotter in a conventional planting system. Base and nitrogen fertilizations were performed according to previous soil analysis. The nitrogen fertilization was made via urea by applying $50 \%$ of the dose at the V4 stage (beginning of tillering) and the rest at the R0 stage (differentiation of the floral primordium). Pest and disease management was carried out in alignment with technical recommendations for irrigated rice crop in Southern Brazil.

Grain harvesting was performed manually, avoiding possible undesirable mixtures between cultivars, when a mean grain moisture of $22 \%$ was reached. Subsequently, the grains were placed in a dryer to reduce the relative humidity to approximately $13 \%$. Subsequently, the grains were processed in a mini MT 2012 Suzuki test rig (Máquinas Suzuki S/A, Santa Cruz do Rio Pardo, SP, Brazil) for peeling and polishing, and the whole grain yield (\%) was obtained after processing. The intrinsic physical quality attributes of the grains were evaluated by a S21 rice grain statistical analyzer (iSuzuki Software, Santa Cruz do Rio Pardo, SP, Brazil) based on the analysis of digital images of each sample. Each sample containing $100 \mathrm{~g}$ of peeled and polished rice passed through a digital image grabber. A video of the grains being moved inside it was recorded and the images were transmitted to an automatic data processing software. The following parameters were determined: length and width of polished grains $(\mathrm{mm})$, percentage of chalky kernel and chalkiness of grains (\%), total chalky area (\%), general defects in grain coloring (burned, moldy, cracked, stained, and yellow grains) (\%), total whiteness (S21 whiteness scale), vitreous grain whiteness (S21 whiteness scale) and non-vitreous grain whiteness (S21 whiteness scale). The S21 whiteness scale ranges from 0 to 200 , in which 200 is the maximum whiteness value. For vitreous whiteness, the mass considered as chalky is discarded.

In addition to these physical attributes, 1,000-grain weight $(\mathrm{g})$ and chemical quality parameters, such as amylose content (\%) and gelatinization temperature (\%), were also evaluated regarding the post-harvest, industrialization, and quality of grains, by the laboratory of Universidade Federal de Pelotas. The amylose content was determined by a colorimetric method adapted by Martínez \& Cuevas (1989), which measures the absorbance of the amylose-iodine complex in a 600 Plus spectrophotometer (Femto Indústria e Comércio de Instrumentos, São Paulo, SP, Brazil). The estimation of gelatinization temperature range was performed according to Martínez \& Cuevas (1989), using a potassium hydroxide solution. After obtaining phenotypic data, the genetic estimates of the traits were analyzed by mixed linear models due to losses of experimental units. The components of variance and genetic parameters were estimated by restricted maximum likelihood (REML) and prediction

Table 1. Cultivars released, crop cycle, and release year by Embrapa's flooded-irrigated rice (Oryza sativa) breeding program for the state of Rio Grande do Sul, Brazil.

\begin{tabular}{lcc}
\hline Cultivar & Release year & Crop cycle \\
\hline IAS 12-9 Formosa & 1972 & Long \\
BR IRGA 409 & 1979 & Middle \\
BR IRGA 410 & 1980 & Middle \\
BR IRGA 411 & 1985 & Middle \\
BR IRGA 412 & 1986 & Middle \\
BR IRGA 413 & 1986 & Middle \\
BR IRGA 414 & 1987 & Short \\
BRS 6 "Chuí" & 1991 & Short \\
BRS 7 "Taim" & 1991 & Middle \\
BRS Ligeirinho & 1995 & Super short \\
BRS Agrisul & 1995 & Middle \\
BRS Bojuru & 1997 & Middle \\
BRS Atalanta & 1999 & Super short \\
BRS Firmeza & 1999 & Short \\
BRS Pelota & 2000 & Middle \\
BRS SCS 113 Tio Taka & 2004 & Long \\
BRS Fronteira & 2005 & Middle \\
BRS Querência & 2005 & Short \\
BRS Cirad 302 & 2010 & Middle \\
BRS Sinuelo CL & 2010 & Middle \\
BRS Pampa & 2011 & Short \\
BRS 358 & 2015 & Short \\
BRS Pampeira & 2016 & Middle \\
\hline
\end{tabular}

Pesq. agropec. bras., Brasília, v.53, n.4, p.453-463, Apr. 2018 DOI: $10.1590 / \mathrm{S} 0100-204 X 2018000400007$ 
of genetic values by the best linear unbiased predictor (Blup). The statistical model was represented by:

$$
\mathrm{Y}=\mathrm{X}_{\mathrm{r}}+\mathrm{Z}_{\mathrm{g}}+\mathrm{W}_{\mathrm{i}}+\varepsilon
$$

in which $\mathrm{Y}$ is the vector of data, $\mathrm{r}$ is the vector of repetition effects (assumed as fixed) added to the general mean, $\mathrm{g}$ is the vector of genotypic effects (assumed as random), $i$ is the vector of effects of the genotype $\times$ environment interaction (random), and $\varepsilon$ is the vector of errors or residues (random). The SelegenREML/Blup statistical software was used for the inference of genotypic means (Resende, 2016).

Estimates of genetic progress followed the approach based on a comparative analysis of cultivars released over the years, obtained by the evaluation of 25 cultivars of irrigated rice developed and released for the state of Rio Grande do Sul by the breeding program of Embrapa exclusively or in partnership with other research institutions (Table 1) between 1972 and 2016 (except for the cultivar BR IRGA 415, whose seeds were not found). The cultivar Bluebelle, of American origin, which was introduced in the 1970s and long cultivated in Southern Brazil, was also included in the experiment to increase its accuracy. Based on the genetic estimates of each trait, the mean annual genetic progress was obtained by a generalized linear regression. The relative genetic progress was estimated as the ratio between the annual gain and the initial intercept, in percentage, in which the initial intercept represents the initial stage of the breeding program.

\section{Results and Discussion}

The estimates of genetic parameters (Table 2) for grain quality traits evidenced a high genetic variability. The high genetic variance indexes together with high heritability coefficients (except for percentage of whole grains and grain defects) showed that a large part of phenotypic variance is explained by genetic variance, minimizing environmental effects. In addition, the high experimental accuracy (above 0.90) obtained for all evaluated characters is an indicator of a high reliability in the inferences of genotypic means. Assays presenting values of accuracy above 0.90 can be considered as having an excellent experimental precision. According to Resende \& Duarte (2007), the inference of experimental accuracy is recommended in trials for the evaluation of cultivars, as it takes into account perspectives from a genetic and statistical point of view, considering the proportions between genetic and residual variations associated with the character under evaluation in addition to the magnitude of residual variation.

The genetic progress achieved by the breeding program in Southern Brazil, evidenced by comparison

Table 2. Variance components obtained by individual REML taking into account the joint analysis of 25 irrigated rice (Oryza sativa) cultivars evaluated in four locations in the state of Rio Grande do Sul, Brazil, regarding the grain quality attributes: whole grain percentage after processing (WG), percentage of chalky area (GYA), percentage of chalky kernel and chalkiness of grains (CK), grain coloring defects (CD), total grain whiteness (GW), and non-vitreous grain whiteness $(\mathrm{NVW})$.

\begin{tabular}{|c|c|c|c|c|c|c|}
\hline $\begin{array}{l}\text { Variance } \\
\text { component }^{(1)}\end{array}$ & $\begin{array}{l}\text { WG } \\
(\%)\end{array}$ & $\begin{array}{c}\text { GYA } \\
(\%)\end{array}$ & $\begin{array}{l}\text { CK } \\
(\%) \\
\end{array}$ & $\begin{array}{l}\text { CD } \\
(\%) \\
\end{array}$ & $\mathrm{GW}^{(2)}$ & $\mathrm{NVW}^{(2)}$ \\
\hline $\mathrm{V}_{\mathrm{g}}$ & 12.80 & 72.46 & 90.91 & 11.23 & 25.25 & 66.24 \\
\hline$V_{\text {int }}$ & 9.15 & 5.98 & 3.19 & 3.23 & 2.51 & 6.19 \\
\hline $\mathrm{V}_{\mathrm{e}}$ & 9.11 & 10.45 & 11.50 & 4.63 & 5.42 & 10.42 \\
\hline$V_{f}$ & 31.06 & 88.88 & 105.61 & 19.08 & 33.18 & 82.86 \\
\hline $\mathrm{h}_{\mathrm{g}}^{2}$ & $0.41 \pm 0.11$ & $0.82 \pm 0.15$ & $0.86 \pm 0.16$ & $0.59 \pm 0.13$ & $0.76 \pm 0.15$ & $0.80 \pm 0.15$ \\
\hline $\mathrm{c}^{2}{ }_{\text {int }}$ & 0.29 & 0.07 & 0.03 & 0.17 & 0.08 & 0.07 \\
\hline $\mathrm{h}^{2}{ }_{\mathrm{mg}}$ & 0.81 & 0.97 & 0.98 & 0.90 & 0.96 & 0.96 \\
\hline $\mathrm{A}_{\mathrm{g}}^{\mathrm{c}}$ & 0.90 & 0.98 & 0.99 & 0.95 & 0.98 & 0.98 \\
\hline $\mathrm{r}_{\mathrm{a}}^{\mathrm{g}}$ & 0.58 & 0.92 & 0.97 & 0.78 & 0.91 & 0.91 \\
\hline$\mu$ & 60.12 & 16.29 & 3.40 & 5.04 & 132.53 & 10.89 \\
\hline
\end{tabular}

${ }^{(1)} \mathrm{V}_{\mathrm{g}}$, genotypic variance; $\mathrm{V}_{\mathrm{int}}$, variance of genotype $\times$ environment interaction; $\mathrm{V}_{\mathrm{e}}$, residual variance; $\mathrm{V}_{\mathrm{f}}$, phenotypic variance; $\mathrm{h}_{\mathrm{g}}^{2}$, heritability of the total genotypic effects; $\mathrm{c}^{2}{ }_{\text {int }}$, coefficient of determination of the effects of genotypes $\times$ environment interaction; $\mathrm{h}^{2}{ }_{\mathrm{mg}}$, heritability, in the wide sense, at the level of middle genotypes; $\mathrm{A}_{\mathrm{g}}^{\mathrm{c}}$, accuracy of selection at the level of middle genotypes; $\mathrm{r}_{\mathrm{a}}^{\mathrm{g}}$, genotypic correlation between genotype and environment; and $\mu$, experimental average. ${ }^{(2)}$ Scale unit of the S21 analyzer (iSuzuki Software, Santa Cruz do Rio Pardo, SP, Brazil). 
of cultivars, is shown in Table 3. Between 1972 and 2016, it was verified that the breeding program had a significant genetic progress for the attributes percentage of whole grains after processing, percentage of chalky kernel and chalkiness of grains, grain chalky area and attributes related to grain whiteness. No significant progress was noted for defects in color in that period. The levels of genetic progress obtained are in agreement with Lopes et al. (2012), who reported a commitment of Embrapa in developing high quality and productive cultivars.

For whole grains percentage after processing (Table 3 and Figure 1), it can be seen that there was a $0.113 \%$ genetic gain of whole grains per year, representing a genetic progress of $0.20 \%$ for this trait, considered the most important among grain quality requirements.

Regarding this trait, the three cultivars recently released were genetically highlighted: BRS Pampeira,

Table 3. Estimates of linear regression parameters and genetic progress for: whole grains percentage after processing (WG), percentage of chalky kernel and chalkiness (CK), percentage of chalky area (GYA), grain coloring defects (CD), total grain whiteness (GW), and non-vitreous grain whiteness (NVW) determined by comparative analysis of 25 irrigated rice (Oryza sativa) cultivars between 1972 and 2016.

\begin{tabular}{|c|c|c|c|c|c|c|}
\hline Parameter & WG (\%) & CK $(\%)$ & GYA $(\%)$ & $\mathrm{CD}(\%)$ & GW & NVW \\
\hline Intercept & 57.82 & 2.24 & 17.95 & 6.1 & 134.07 & 11.53 \\
\hline Slope (gain year ${ }^{-1}$ ) & $0.113^{* *}$ & $-0.031^{*}$ & $-0.138 * *$ & $-0.052^{\mathrm{ns}}$ & $-0.103 * *$ & $-0.094 * *$ \\
\hline t-value & 2.91 & -2.34 & -3.70 & -0.99 & -3.23 & -3.80 \\
\hline p-value & 0.008 & 0.028 & 0.001 & 0.664 & 0.004 & 0.001 \\
\hline Relative progress (\%) & 0.20 & -1.38 & -0.77 & - & -0.08 & -0.82 \\
\hline
\end{tabular}

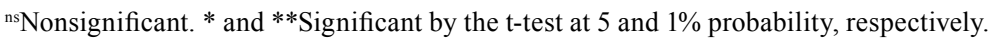

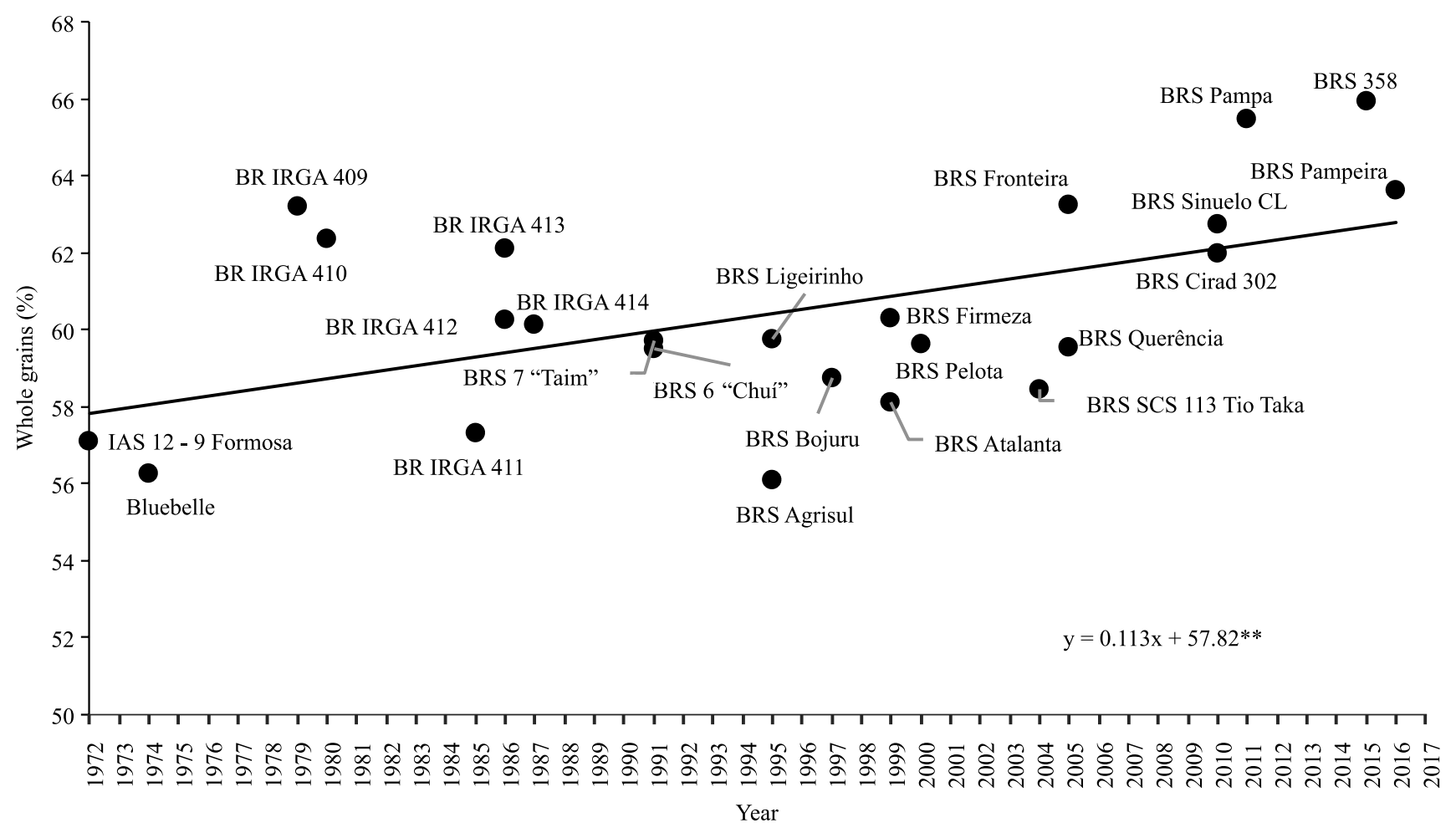

Figure 1. Genetic progress for whole grains percentage after processing obtained by linear regression of comparative trials of irrigated rice (Oryza sativa) cultivars released between 1972 and 2016. **Significant by the t-test at 1\% probability. 
BRS Pampa, and BRS 358. BRS Pampeira presented an average yield of $63 \%$ of whole grains, confirming data of Magalhães Júnior et al. (2017), who found yields greater than $62 \%$ for polished whole grains. The cultivar BRS Pampa presented a $65 \%$ yield of whole grains. It is considered an excellent cultivar in Rio
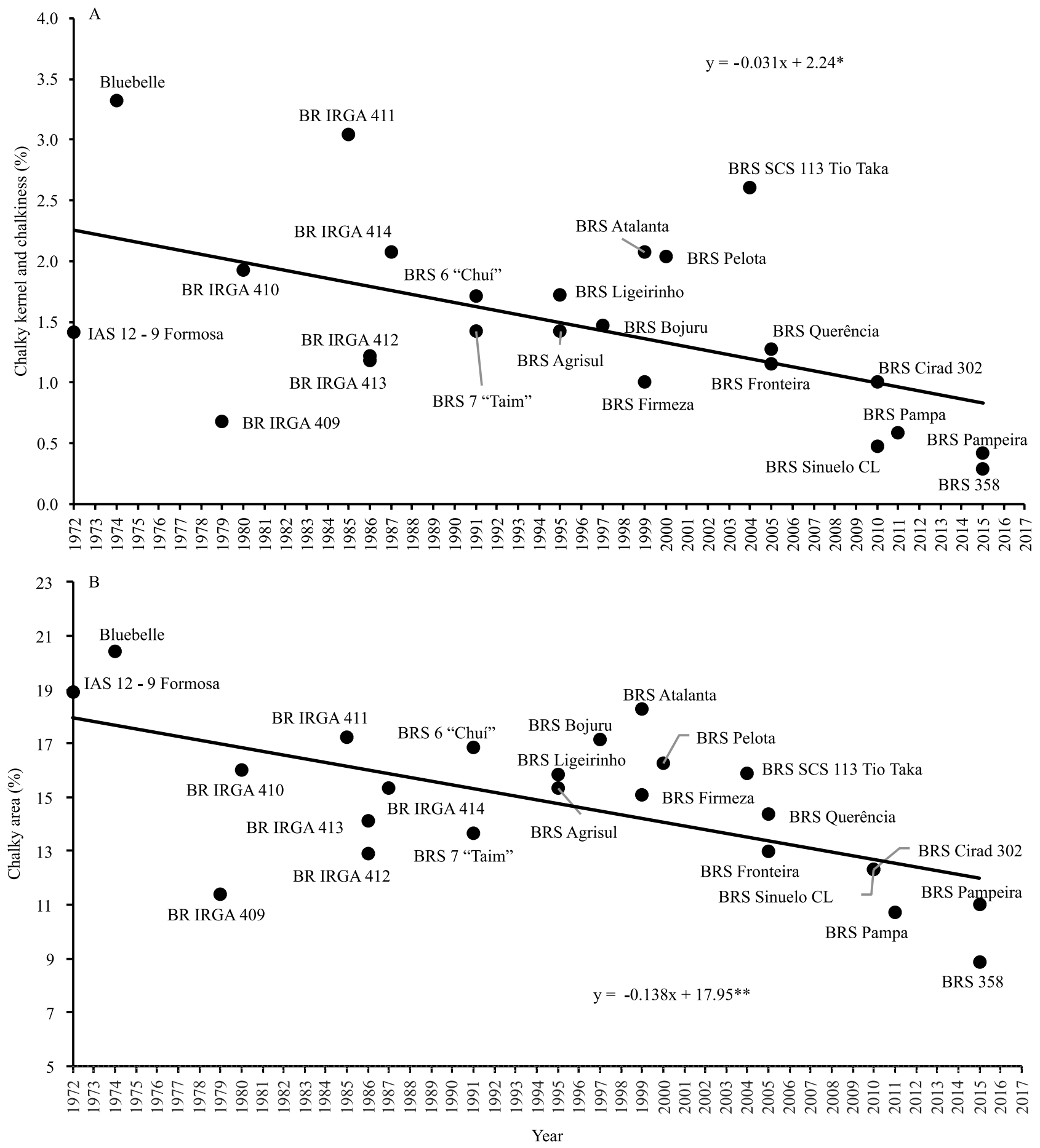

Figure 2. Genetic progress for percentage of chalky kernel and chalkiness of grains (A) and total chalky area (B) after processing determined by linear regression of comparative trials of irrigated rice (Oryza sativa) cultivars released between 1972 and 2016. * and **Significant by the t-test at 5 and $1 \%$ probability, respectively. 
Grande do Sul regarding grain quality (Magalhães Júnior et al., 2012). It has a genetic base similar to the one of the cultivar IRGA 417, which is known nationally by the industry for presenting "premium" or "noble" grains (Champagne et al., 2010). However, BRS 358 stood out for presenting $66 \%$ of industrial yield of whole grains. This was expected because it is a fast grain cultivation intended for oriental cuisine.

It should be noted that even though the irrigated rice cultivars BR IRGA 409 and BR IRGA 410 are old cultivars (released in 1979 and 1980, respectively), they presented high yields after processing. These cultivars caused the so-called green rice revolution in Brazil due to a new plant architecture that allowed increasing the productivity potential of Rio Grande do Sul (Streck et al., 2017), together with good grain quality attributes.

Borges et al. (2009) mentioned that grain quality attributes are the main selection criteria since the end of the 1980s, and the selection pressure for factors related to such traits intensified.

Percentage of chalky kernel and chalkiness of grains are attributes affected by the performance of physiological disturbances, which may prevent the normal filling of grains. Therefore, these traits are of great concern in rice breeding, as they are key factors in determining the quality and the price of rice (Yoshioka et al., 2007). Following this tendency, the breeding program obtained a high genetic progress of $-1.38 \%$ for the 45 -year period in question, representing an annual decreasing tendency of $-0.031 \%$ in the incidence of such undesired attributes in irrigated rice crops (Table 3).

The response of the cultivars to the percentage of chalky kernel and chalkiness of grains (Figure 2 A) was similar to rankings for quality of whole grains yield after processing. This evidenced the high specificity of the cultivars BRS Pampeira, BRS Pampa and BRS 358 for quality requirements. In addition, the cultivar BRS Sinuelo CL, released in 2010, also presented a low incidence of chalky kernel and chalkiness of grains.

As a consequence of this decrease in chalky kernel and chalkiness of grains, the total grain chalky area also decreased, resulting in a relative genetic progress of $-0.77 \%$ (Table 3 ). This reduction of $-0.138 \%$ per year led the research to obtain genetically superior cultivars for this trait (Figure 2B).

The traits that determine grain quality, such as coloring and parameters related to grain appearance, are intrinsically related to consumer acceptability, which may result in depreciation of the product in the market.

According to Table 3, there were no significant gains for coloring defects. However, this is a very peculiar trait, since each rice cultivar responds in a different way to the incidence of biotic and abiotic factors that may cause metabolic damages to grains, a fact that will lead to coloring defects.

However, for total whiteness and non-vitreous whiteness (Table 3, Figures 3A and 3B), there were significant genetic gains represented by an annual decrease of $-0.103 \%$ and $-0.094 \%$, respectively. In this sense, the program was successful in the improvement process, resulting in an annual genetic progress of $-0.08 \%$ for total whiteness and $-0.82 \%$ for non-vitreous whiteness, that is, a decrease in the total grain opacity. Therefore, recently introduced cultivars present the most vitreous grains, a parameter currently widely used in irrigated rice cultivation.

It should be noted that other parameters related to the constitution and appearance of grains also need to be carefully emphasized, since they may influence the consumer market. Table 4 shows that there is a great variation both in grain size, which results in different grain shapes, and in the grain mass of the cultivars. Regarding grain shape, three cultivars were classified as rounded, that is, they had a ratio between length and width lower than $2.0(<1.50=$ rounded, $1.50-2.00=$ semi-rounded), which is characteristic of the subspecies Japonica. The other cultivars are considered to be of the subspecies Indica, which present grains with an elongated format. Such physical grain variations as to shapes and differences in the biochemical constitution are responsible for the great genetic variability for 1,000-grain mass, evidencing a fluctuation between $23.65 \mathrm{~g}$, for BRS 358 , and $35.50 \mathrm{~g}$ for BR IRGA 411.

In addition to the physical attributes of grains, biochemical characteristics are fundamental to determine the sensory and culinary characteristics of rice. The amylose content is one of the parameters most widely used to determine the technological and consumption quality of rice. Therefore, it should be taken into account in the breeding of cultivars (Walter et al., 2008). The data shown in Table 4 reveal a research for high or at least intermediate amylose contents, providing loose and soft grains after cooking. Such grains meet the market's requirements. Thus, only 
cultivars developed for market niches, e.g., related to Japanese cuisine, have low amylose content.
In addition to amylose content, gelatinization temperature (GT) is also an extremely important indirect parameter for rice quality, as it evaluates the
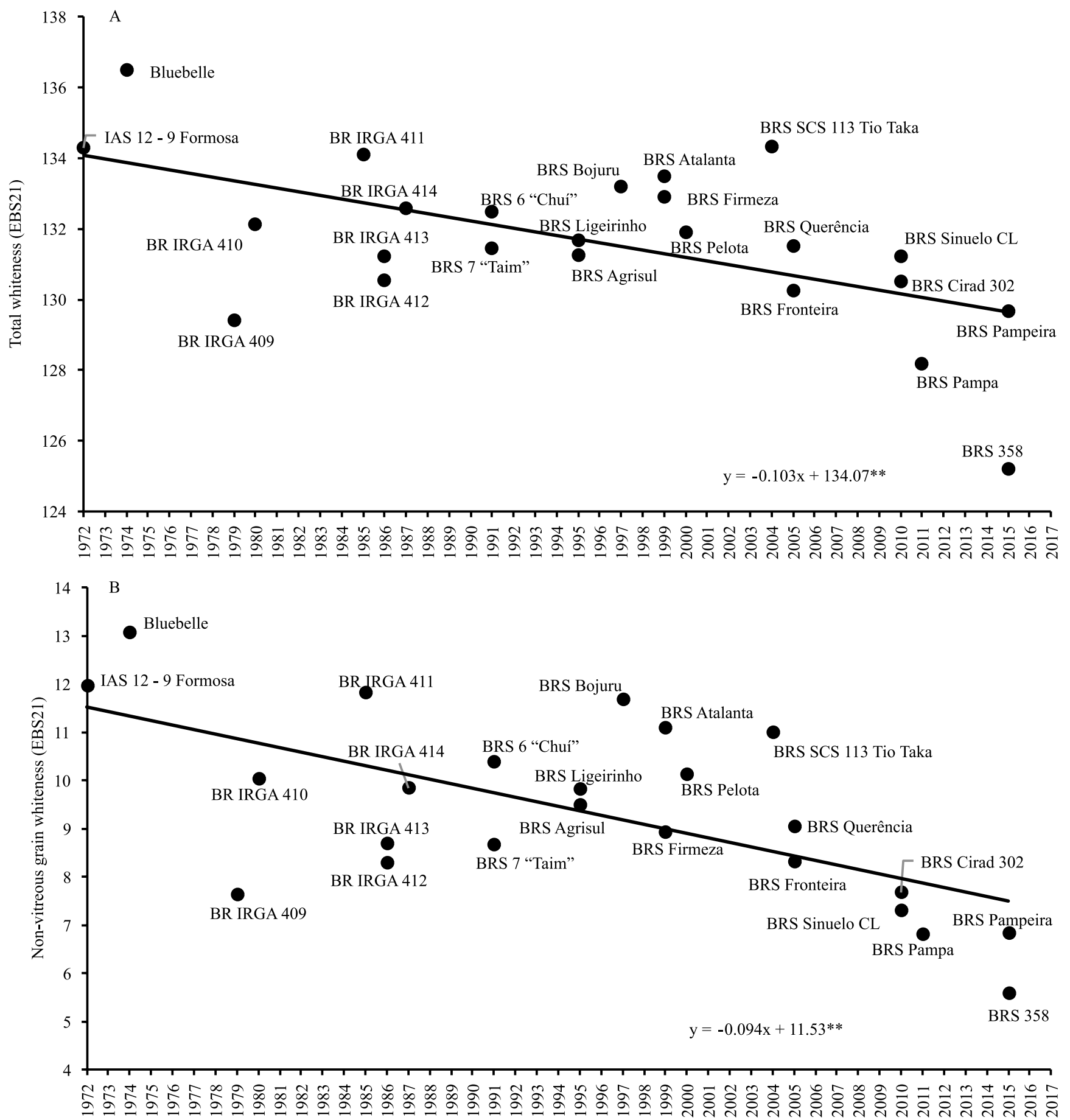

Year

Figure 3. Genetic progress for the percentage of total whiteness (A) and non-vitreous grain whiteness (B) after processing determined by linear regression of comparative trials of irrigated rice (Oryza sativa) cultivars released between 1972 and 2016. ${ }^{*}$ *Significant by the $\mathrm{t}$-test at $1 \%$ probability. 
cooking resistance index and is related to cooking time. According to Table 4, it was verified that the majority of the cultivars presented a GT between low (from 63 to $68^{\circ} \mathrm{C}$ ) and intermediate (from 69 to $73^{\circ} \mathrm{C}$ ). This evidences that most of the cultivars released require less water and less time to cook.

In this context, it can be highlighted that the rice breeding program in Rio Grande do Sul has been highly successful in the development of cultivars with a wide range of attributes of interest to the most varied sectors of the irrigated rice chain.

However, it is worth noting that the attributes related to the grain quality of irrigated rice are highly related not only to genetic factors, but also to environmental ones (Cameron et al., 2008; Hakata et al., 2012; Lyman

Table 4. Response of flooded-irrigated rice (Oryza sativa) cultivars released by Embrapa for the state of Rio Grande do Sul, Brazil, from 1972 to 2016, in relation to the attributes: grain length (GL), grain width (GWi), grain length and width ratio (GLWR), 1,000-grain weight (OTGM), amylose content (AC), and gelatinization temperature (GT).

\begin{tabular}{lcccccc}
\hline Cultivar & $\begin{array}{c}\text { GL } \\
(\mathrm{mm})\end{array}$ & $\begin{array}{c}\text { GWi } \\
(\mathrm{mm})\end{array}$ & $\begin{array}{c}\text { GLWR }^{(1)} \\
\text { OTGM } \\
(\mathrm{g})\end{array}$ & $\mathrm{AC}^{(2)}$ & $\mathrm{GT}^{(3)}$ \\
\hline IAS 12-9 Formosa & 4.93 & 2.59 & 1.90 & 29.35 & $\mathrm{~B}$ & $\mathrm{~B}$ \\
BR IRGA 409 & 6.38 & 2.03 & 3.14 & 26.80 & $\mathrm{~A}$ & $\mathrm{~B}$ \\
BR IRGA 410 & 6.69 & 2.10 & 3.18 & 29.25 & $\mathrm{~A}$ & $\mathrm{~B}$ \\
BR IRGA 411 & 6.76 & 2.19 & 3.08 & 35.50 & - & - \\
BR IRGA 412 & 6.51 & 2.05 & 3.17 & 29.00 & $\mathrm{~A}$ & $\mathrm{~B}$ \\
BR IRGA 413 & 6.12 & 2.15 & 2.85 & 27.45 & $\mathrm{I}$ & $\mathrm{I} / \mathrm{B}$ \\
BR IRGA 414 & 6.61 & 2.16 & 3.06 & 29.20 & $\mathrm{~A}$ & $\mathrm{~B}$ \\
BRS 6 “Chuí" & 6.10 & 2.05 & 2.97 & 23.90 & $\mathrm{~A}$ & $\mathrm{I} / \mathrm{B}$ \\
BRS 7 "Taim" & 6.46 & 2.05 & 3.15 & 28.40 & $\mathrm{I}$ & $\mathrm{I} / \mathrm{B}$ \\
BRS Ligeirinho & 6.03 & 2.09 & 2.88 & 25.35 & - & - \\
BRS Agrisul & 6.69 & 1.94 & 3.45 & 25.85 & - & - \\
BRS Bojuru & 5.20 & 2.60 & 2.00 & 29.50 & $\mathrm{~B}$ & $\mathrm{~B}$ \\
BRS Atalanta & 6.55 & 1.99 & 3.29 & 25.75 & $\mathrm{~A}$ & $\mathrm{I}$ \\
BRS Firmeza & 6.79 & 2.09 & 3.25 & 29.00 & $\mathrm{I} / \mathrm{B}$ & $\mathrm{I}$ \\
BRS Pelota & 6.49 & 2.08 & 3.11 & 28.25 & $\mathrm{I}$ & $\mathrm{I} / \mathrm{B}$ \\
BRS SCS 113 Tio Taka & 6.73 & 2.09 & 3.23 & 28.05 & $\mathrm{~A}$ & $\mathrm{I}$ \\
BRS Fronteira & 6.66 & 2.10 & 3.17 & 30.20 & $\mathrm{~A}$ & $\mathrm{~B}$ \\
BRS Querência & 6.59 & 1.98 & 3.33 & 27.00 & $\mathrm{I}$ & $\mathrm{I} / \mathrm{B}$ \\
BRS Sinuelo CL & 6.65 & 2.11 & 3.16 & 29.25 & $\mathrm{~A}$ & $\mathrm{~A}$ \\
BRS Cirad 302 & 6.61 & 2.00 & 3.30 & 26.05 & $\mathrm{I}$ & $\mathrm{I} / \mathrm{A}$ \\
BRS Pampa & 6.62 & 2.01 & 3.29 & 26.45 & $\mathrm{~A}$ & $\mathrm{~B}$ \\
BRS 358 & 5.08 & 2.55 & 1.99 & 23.65 & $\mathrm{~B}$ & $\mathrm{I}$ \\
BRS Pampeira & 6.88 & 2.01 & 3.43 & 29.40 & $\mathrm{~A}$ & $\mathrm{~B}$ \\
\hline
\end{tabular}

${ }^{(1)}$ Grain shape in relation to caryopsis length and width: $<1.50=$ rounded, $1.50-2.00=$ semi-rounded, $2.01-2.75=$ half-elongated, $2.76-3.50=$ elongated, $>3.50=$ very elongated. ${ }^{(2)} \mathrm{B}=$ low $(<22 \%), \mathrm{I}=$ intermediate (23-27\%), A = high $(>28-33 \%) .{ }^{(3)} \mathrm{B}=$ low $\left(63-68^{\circ} \mathrm{C}\right), \mathrm{I}=$ intermediate $\left(69-73^{\circ} \mathrm{C}\right), \mathrm{A}=\operatorname{high}\left(74-80^{\circ} \mathrm{C}\right)$. et al., 2013; Li et al., 2014; Xu et al., 2015). Physical attributes are very complex quantitative traits because they are controlled by maternal and cytoplasmic effects. Therefore, many genetic mechanisms and interactions with the environment are still obscure (Shi et al., 2002; Zhou et al., 2009).

Adverse environmental and crop management conditions directly affect the formation and the filling of grains, and, consequently, may lead to damages to grains resulting from a changed metabolism. Such damages can be attributed to the effects of harmful factors on plants both due to biotic (pests, weeds and diseases) and abiotic factors (climatic and soil conditions). In addition, the management of harvesting time and procedures, as well as the post-harvest processing process, are also relevant to obtain a maximum expression of the quality attributes of a cultivar.

It is worth highlighting that innumerable advances in management and post-harvest technologies were obtained in recent years by the most varied productive sectors, allowing rice cultivars to more easily express their genetic potential regarding grain quality attributes.

\section{Conclusions}

1. The flooded-irrigated rice (Oryza sativa) cultivars released from 1972 to 2016 show genetic progress regarding grain quality attributes, of: $0.20 \%$ for the percentage of whole grains after processing, $-1.38 \%$ for the percentage of chalky kernel and chalkiness of grains, $-0.77 \%$ for chalky area, $-0.08 \%$ for total whiteness, and $-0.82 \%$ for non-vitreous grain whiteness.

2. The middle-cycle cultivars BRS Pampeira (2016) and Sinuelo CL (2010) and the short-cycle cultivars BRS 358 (2015) and BRS Pampa (2011) stand out due to a favorable genotypic response to the main physical attributes of grain quality.

3. Most of the flooded-irrigated rice cultivars evaluated show high amylose content and low gelatinization temperature.

\section{Acknowledgments}

To Embrapa Clima Temperado, for technical, scientific, and infrastructure contributions to carry out the experiments. 


\section{References}

ACOMPANHAMENTO DA SAFRA BRASILEIRA [DE] GRÃOS: safra 2016/17: sétimo levantamento, v.4, n.7, abr. 2017. 157p. Available at: <http://www.conab.gov.br/OlalaCMS/uploads/ arquivos/17_04_17_17_20_55_boletim_graos_abr_2017.pdf $>$. Accessed on: May 052017.

BORGES, V.; SOARES, A.A.; RESENDE, M.D.V. de; REIS, M.S.; CORNÉLIO, V.M.O.; SOARES, P.C. Progresso genético do programa de melhoramento de arroz de terras altas de Minas Gerais utilizando modelos mistos. Revista Brasileira de Biometria, v.27, p.478-490, 2009.

BRESEGHELlO, F.; RANGEL, P.H.N.; MORAIS, O.P. Ganho de produtividade pelo melhoramento genético do arroz irrigado no nordeste do Brasil. Pesquisa Agropecuária Brasileira, v34, p.399-407, 1999. DOI: 10.1590/S0100-204X1999000300011.

CAMERON, D.K.; WANG, Y.J.; MOLDENHAUER, K.A. Comparison of physical and chemical properties of mediumgrain rice cultivars grown in California and Arkansas. Journal of Food Science, v.73, p.72-78, 2008. DOI: 10.1111/j.17503841.2007.00631.x.

CHAMPAGNE, E.T.; BETT-GARBER, K.L.; FITZGERALD, M.A.; GRIMM, C.C.; LEA, J.; OHTSUBO, K.; JONGDEE, S.; XIE, L.; BASSINELLO, P.Z.; RESURRECCIÓN, A.; AHMAD, R.; HABIBI, F.; REINKE, R. Important sensory properties differentiating premium rice varieties. Rice, v.3, p.270-281, 2010. DOI: $10.1007 / \mathrm{s} 12284-010-9057-4$.

DOVALE, J.C.; SOARES, P.C.; CORNÉLIO, V.M.O.; REIS, M.S.; BORGES, V.; BISI, R.B.; SOARES, A.A.; FRITSCHE-NETO, R. Contribuição genética na produtividade do arroz irrigado em Minas Gerais no período de 1998 a 2010. Bragantia, v.71, p.460466, 2012. DOI: 10.1590/S0006-87052012000400002.

EDWARDS, J.D.; JACKSON, A.K.; MCCLUNG, A.M. Genetic architecture of grain chalk in rice and interactions with a low phytic acid locus. Field Crops Research, v.205, p.116-123, 2017. DOI: 10.1016/j.fcr.2017.01.015.

FITZGERALD, M.A.; HAMILTON, N.R.S.; CALINGACION, M.N.; VERHOEVEN, H.A.; BUTARDO, V.M. Is there a second gene for fragrance in rice? Plant Biotechnology Journal, v.6, p.416-423, 2008a. DOI: 10.1111/j.1467-7652.2008.00327.x.

FITZGERALD, M.A.; MCCOUCH, S.R.; HALL, R.D. Not just a grain of rice: the quest for quality. Trends in Plant Science, v.14, p.133-139, 2008b. DOI: 10.1016/j.tplants.2008.12.004.

HAKATA, M.; KURODA, M.; MIYASHITA, T.; YAMAGUCHI, T.; KOJIMA, M.; SAKAKIBARA, H.;MITSUI, T.; YAMAKAWA, $H$. Suppression of $\alpha$-amylase genes improves quality of rice grain ripened under high temperature. Plant Biotechnology Journal, v.10, p.1110-1117, 2012. DOI: 10.1111/j.1467-7652.2012.00741.x.

LEE, I.; SEO, Y.-S.; COLTRANE, D.; HWANG, S.; OH, T.; MARCOTTE, E.M.; RONALD, P.C. Genetic dissection of the biotic stress response using a genome-scale gene network for rice. Proceedings of the National Academy of Sciences of the United States of America, v.108, p.18548-18553, 2011. DOI: 10.1073/ pnas. 1110384108 .
LI, Y.; FAN, C.; XING, Y.; YUN, P.; LUO, L.; YAN, B.; PENG, B.; XIE, W.; WANG, G. LI, X.; XIAO, J.; XU, C.; HE, Y. Chalk5 encodes a vacuolar $\mathrm{H}^{+}$- translocating pyrophosphatase influencing grain chalkiness in rice. Nature Genetics, v.46, p.398-404, 2014. DOI: 10.1038/ng.2923.

LOPES, M.A.; FALEIRO, F.G.; FERREIRA, M.E.; LOPES, D.B.; VIVIAN, R.; BOITEUX, L.S. Embrapa's contribution to the development of new plant varieties and their impact on Brazilian agriculture. Crop Breeding and Applied Biotechnology, v.12, p.31-46, 2012. DOI: 10.1590/S1984-70332012000500005.

LYMAN, N.B.; JAGADISH, K.S.; NALLEY, L.L.; DIXON, B.L.; SIEBENMORGEN, T. Neglecting rice milling yield and quality underestimates economic losses from high-temperature stress. Plos One, v.8, e72157, 2013. DOI: 10.1371/journal.pone.0072157.

MAGALHÃES JÚNIOR, A.M. de; MORAIS, O.P. de; FAGUNDES, P.R.R.; COLOMBARIFILHO, J.M.;FRANCO, D.F.; CORDEIRO, A.C.C.; PEREIRA, J.A.; RANGEL, P.H.N.; MOURA NETO, F.P.; STRECK, E.A.; AGUIAR, G.A.; FACCHINELLO, P.H.K. BRS Pampeira: new irrigated rice cultivar with high yield potential. Crop Breeding and Applied Biotechnology, v.17, p.78-83, 2017. DOI: 10.1590/1984-70332017v17n1c13.

MAGALHÃES JÚNIOR, A.M. de; MORAIS, O.P. de; FAGUNDES, P.R.R.; MOURA NETO, F.P.; FRANCO, D.F.; NEVES, P. de C.F.; NUNES, C.D.M.; RANGEL, P.H.N.; PETRINI, J.A.; SEVERO, A.C.M. BRS Pampa: cultivar de arroz irrigado de alta produtividade e excelência na qualidade de grãos. Pelotas: Embrapa Clima Temperado, 2012. 8p. (Embrapa Clima Temperado. Comunicado técnico, 282).

MARTÍNEZ, C.; CUEVAS, F. Evaluación de la calidad culinaria y molinera del arroz: guía de estudio. Cali: Centro Internacional de Agricultura Tropical, 1989. 75p.

MINGOTTE, F.L.C.; HANASHIRO, R.K.; FORNASIERI FILHO, D. Características físico-químicas do grão de cultivares de arroz em função da adubação nitrogenada. Semina: Ciências Agrárias, v.33, p.2605-2618, 2012. Suplemento 1. DOI: 10.5433/1679-0359.2012v33Supl1p2605.

RESENDE, M.D.V. de; DUARTE, J.B. Precisão e controle de qualidade em experimentos de avaliação de cultivares. Pesquisa Agropecuária Tropical, v.37, p.182-194, 2007.

RESENDE, M.D.V. de. Software Selegen-REML/BLUP: a useful tool for plant breeding. Crop Breeding and Applied Biotechnology, v.16, p.330-339, 2016. DOI: 10.1590/198470332016v16n4a49.

SHI, C.H.; WU, J.G.; LOU, X.B.; ZHU, J.; WU, P. Genetic analysis of transparency and chalkiness area at different filling stages of rice (Oryza sativa L.). Field Crops Research, v.76, p.1-9, 2002. DOI: 10.1016/S0378-4290(02)00011-4.

SMIDERLE, O.J.; DIAS, C.T. dos S. Época de colheita e qualidade fisiológica de sementes em arroz irrigado (Oryza sativa L. cv. BRS Roraima). Pesquisa Agropecuária Tropical, v.38, p.188-194, 2008.

STRECK, E.A.; AGUIAR, G.A.; MAGALHÃES JÚNIOR, A.M. de; FACCHINELLO, P.H.K.; OLIVEIRA, A.C. de. Variabilidade fenotípica de genótipos de arroz irrigado via análise multivariada. 
Revista Ciência Agronômica, v.48, p.101-109, 2017. DOI: 10.5935/1806-6690.20170011.

TABIEN, R.E.; SAMONTE, S.O.P.B.; MCCLUNG, A.M. Fortyeight years of rice improvement in Texas since the release of cultivar Bluebonnet in 1944. Crop Science, v.48, p.2097-2106, 2008. DOI: $10.2135 /$ cropsci2007.12.0680.

WALTER, M.; MARCHEZAN, E.; AVILA, L.A. de. Arroz: composição e características nutricionais. Ciência Rural, v.38, p.1184-1192, 2008. DOI: 10.1590/S0103-84782008000400049.

XU, Q.; CHEN, W.; XU, Z. Relationship between grain yield and quality in rice germplasms grown across different growing areas. Breeding Science, v.65, p.226-232, 2015. DOI: 10.1270/ jsbbs.65.226.
YOSHIOKA, Y.; IWATA, H.; TABATA, M.; NINOMIYA, S.; OHSAWA, R. Chalkiness in rice: potential for evaluation with image analysis. Crop Science, v.47, p.2113-2120, 2007. DOI: 10.2135/cropsci2006.10.0631sc.

ZEIGLER, R.S.; BARCLAY, A. The relevance of rice. Rice, v.1, p.3-10, 2008. DOI: 10.1007/s12284-008-9001-z.

ZHOU, L.J.; JIANG, L.; ZHAI, H.Q.; WAN, J.M. Current status and strategies for improvement of rice grain chalkiness. Hereditas, v.31, p.563-572, 2009. DOI: 10.3724/SP.J.1005.2009.00563.

ZHOU, Z.; ROBARDS, K.; HELLIWELL, S.; BLANCHARD, C. Composition and functional properties of rice. International Journal of Food Science and Technology, v.37, p.849-868, 2002. DOI: 10.1046/j.1365-2621.2002.00625.x.

Received on April 19, 2017 and accepted on July 17, 2017 